\title{
UANG ELEKTRONIK, UANG DIGITAL (CRYPTOCURRENCY) DAN FATWA DSN-MUI NO.116 TENTANG UANG ELEKTRONIK
}

\author{
Mulvi Aulia ${ }^{1}$
}

\section{Abstrak}

Seiring perkembangan zaman yang berdampak pada perkembangan teknologi di mana dunia saat ini sudah mengenal apa yang disebut internet, sistem pembayaran pun menemukan arah baru. Ada yang menginginkan digitalisasi sistem pembayaran namun tetap menggunakan instrumen konvensional, maka muncullah uang elektronik. Namun ada juga yang menginginkan digitalisasi sistem pembayaran dengan menggunakan instrumen digital juga, maka muncullah uang digital atau dikenal dengan cryptocurrency. Di Indonesia otoritas keuangan Sentral baru menerbitkan izin untuk uang elektronik begitu juga dengan Dewan Syariah Nasional Majelis Ulama Indonesia yang mengeluarkan fatwa tentang kebolehan uang elektronik. Pada kenyataannya masyarakat Indonesia selain telah menggunakan uang elektronik mereka juga telah menggunakan uang digital.

Kata Kunci: uang elektronik, cryptocurrency, fatwa

\section{Abstract}

Along with the times that have an impact on technological developments in which the world is now familiar with internet, payment systems are finding new directions. There are those who want to digitize the payment system but still use conventional instruments, so electronic money appears. But there are also those who want to digitize their payment system using digital instruments as well, so digital money appears, known as cryptocurrency. In Indonesia, the central financial authority has only issued licenses for electronic money as well as the National Sharia Council of the Indonesian Ulama Council which issued a fatwa on the permissibility of electronic money. In fact, Indonesian people, besides using electronic money, have also used digital money.

Keywords: electronic money, cryptocurrency, fatwa

\footnotetext{
${ }^{1}$ Fakutas Syariah dan Ekonomi Islam (FSEI) Institut Ilmu Al-Qur'an Jakarta, Email: opiaulia7@gmail.com
} 


\section{A. PENDAHULUAN}

Pada saat manusia belum mengenal uang, transaksi untuk bertukar kepemilikan dilakukan dengan cara barter atau menukar kepemilikan seseorang dengan kepemilikan orang lain. Hal ini dirasa tidak efisien bahkan sulit dilakukan, bayangkan saja apabila seseorang ingin memiliki kerbau sedang ia memiliki seekor sapi. Ia harus mencari orang yang berkeinginan memiliki sapi dan mempunyai kerbau. Atau orang yang ingin memiliki ikan pada saat itu ia memiliki selembar kain, ia harus mencari atau menemukan orang yang yang ingin memiliki kain dan orang tersebut harus mempunyai ikan (Marthon, 2004:115-116).

Manusia adalah makhluk yang diberi akal pikiran oleh Allah, karenanya secara alamiah ia mampu menemukan solusi atas masalahnya sendiri. Untuk keluar dari kesulitan transaksi dengan sistem barter, ditemukanlah alat tukar yang dianggap berharga dan diterima oleh orang banyak. Peradaban Romawi menggunakan garam sebagai sesuatu itu yang dianggap berharga dan bisa dijadikan sebagai alat untuk mengupah pekerja. terbukti hingga sekarang orang menyebut upah dengan kata sallary, dimana sallary diadopsi dari bahasa latin yaitu sallarium yang berarti garam (Hasan, 2004:12).

Permasalahan selanjutnya yaitu benda-benda semacam garam, mudah rusak, apabila dibawa dalam jumlah banyak membutuhkan transportasi dan biaya yang tidak sedikit. Ia pun mudah rusak, lenyap dan tidak bisa digunakan secara massal. Sejarah mencatat uang pertama kali digunakan pada abad ke-10 sebelum Masehi. Bangsa Tiongkok menggunakan logam berjenis emas dan perak untuk dijadikan alat tukar dan selanjutnya kepemilikan atas emas dan perak diwakili oleh kertas. Dalam bukunya Hystory of The Arabs, Philip K. Hitty menyatakan bahwa mata uang kerajaan kerajaan Romawi dan Arabs pertama dibuat pada abad ke-1 Sebelum Masehi (Hitty, 2014:84). Setelah adanya negara-negara atau yang disebut nation, barulah Uang kartal atau uang yang disahkan oleh negara dijadikan sebagai alat tukar (Hasan, 2005:79-80).

Dalam Kamus Besar Bahasa Indonesia, uang adalah alat tukar atau standar pengukur nilai (kesatuan hitungan) yang sah, dikeluarkan oleh pemerintah suatu negara berupa kertas, emas, perak, atau logam lain yang dicetak dengan bentuk dan gambar tertentu. Uang juga berarti harta, kekayaan (Kamus Besar Bahasa Indonesia).

\footnotetext{
UANG ELEKTRONIK, UANG DIGITAL (CRYPTOCURRENCY) DAN

16 FATWA DSN-MUI NO.116 TENTANG UANG ELEKTRONIK Mulvi Aulia
} 
Di Indonesia uang adalah alat pembayaran yang berbentuk uang kertas, uang logam, kartu kredit, uang giral, uang digital dan lain-lain yang dikeluarkan oleh lembaga keuangan. Penggunaan uang biasa dilakukan untuk transaksi tunai maupun transaksi elektronik. Transaksi elektronik adalah perbuatan hukum yang dilakukan menggunakan komputer, jaringan komputer atau media elektronik lainya.

Seiring dengan perkembangan teknologi khususnya dalam sistem pembayaran, pertumbuhan dan alat pembayaran juga mengalami peningkatan yang begitu pesat. penggunaan teknologi modern sebagai instrumen pembayaran non tunai baik dalam skala domestik maupun internasional juga berkembang pesat, hal ini memicu berbagai inovasi yang mengarah Dalam penggunaannya yang semakin efisien, aman, cepat dan nyaman (Abdullah, 2006:9).

Dampak dari perkembangan tersebut yaitu munculnya beragam alat pembayaran mutakhir, mulai dari derivasi uang kartal dalam bentuk elektronik atau disebut uang elektronik, hingga uang digital dimana penggambaran akan hidup didunia maya (internet) yang memiliki suatu sistem dimana setiap orang pribadi memiliki buku besar transaksi (ledger) dan/atau currency nya sendiri (desentralisasi), sistim ini dikenal dengan istilah blockchain dan hasil minning (penambangannya) disebut dengan cryptocurrency.

Menurut Bank Indonesia, uang elektronik adalah instrument pembayaran yang memenuhi unsur sebagai berikut:

1. Diterbitkan atas dasar nilai uang yang disetor terlebih dahulu kepada penerbit.

2. Nilai uang disimpan secara elektronik dalam suatu media server atau chip.

3. Digunakan sebagai alat pembayaran kepada pedagang yang bukan merupakan penerbit uang elektronik tersebut; dan

4. Nilai uang elektronik yang dikelola oleh penerbit bukan merupakan simpanan sebagaimana dimaksud dalam Undangundang yang mengatur mengenai perbankan (Peraturan Bank Indonesia No. 20/6/2018).

Sedangkan dalam fatwa DSN-MUI No.116 Tahun 2017 tentang uang elektronik syariah disebutkan bahwa uang elektronik adalah alat pembayaran yang memenuhi unsur-unsur sebagai berikut: 
1. Diterbitkan atas dasar nilai uang yang disetor terlebih dahulu kepada penerbit.

2. Jumlah nominal uang disimpan secara elektronik dalam suatu media yang teregistrasi.

3. Jumlah nominal uang elektronik yang dikelola oleh penerbit bukan merupakan simpanan sebagaimana dimaksud dalam undang-undang yang mengatur mengenai perbankan, dan

4. Digunakan sebagai alat pembayaran kepada pedagang yang bukan merupakan penerbit uang elektronik tersebut.

Dalam fatwa tersebut juga dikemukakan bahwa uang elektronik syariah adalah uang elektronik yang sesuai dengan prinsip-prinsip syariah, Ia boleh digunakan sebagai alat pembayaran dengan mengikuti ketentuan yang tercantum dalam fatwa (Fatwa DSN-MUI No. 107 tentang Uang Elektronik Syariah).

Dilansir dari laman Bank Indonesia, jenis uang elektronik berdasarkan tercatat atau tidaknya data identitas pemegang pada penerbit uang elektronik dibagi menjadi dua:

1. Uang elektronik registered, yaitu itu uang elektronik yang data identitas pemegangnya tercatat atau terdaftar pada penerbit uang elektronik. Dalam hal ini penerbit harus menerapkan prinsip mengenal nasabah dalam menerbitkan uang elektronik yang teregistrasi.

2. Uang Elektronik unregistered, merupakan Uang Elektronik yang data identitas pemegangnya tidak tercatat/terdaftar pada penerbit Uang Elektronik (Bank Indonesia, 2021).

Hingga November 2020 tercatat ada 56 perusahaan berstatus penerbit uang elektronik yang memperoleh izin dari Bank Indonesia dalam sistem pembayaran dan pengelolaan uang Rupiah (Bank Indonesia, 2021).

\section{B. METODE PENELITIAN}

Pada penelitian ini, penulis akan membahas hal yang berhubungan dengan uang elektronik dari sisi pemaknaan. Baik secara literasi maupun penerapannya sekaligus perbedaannya dengan istilah-istilah yang sejenis dalam lingkup sistim pembayaran. Kemudian penulis juga akan mengemukakan maksud kalimat "Jumlah nominal uang disimpan secara elektronik dalam suatu media yang teregistrasi" yang tercantum dalam fatwa DSN MUI tentang uang elektronik poin 2, dibandingkan

\footnotetext{
UANG ELEKTRONIK, UANG DIGITAL (CRYPTOCURRENCY) DAN

18 FATWA DSN-MUI NO.116 TENTANG UANG ELEKTRONIK Mulvi Aulia
} 
dengan "Nilai uang disimpan secara elektronik dalam suatu media server atau chip" yang disampaikan oleh Bank Indonesia tentang uang elektronik.

Penelitian ini menggunakan pendekatan kualitatif, dengan metode library research dan wawancara yang memanfaatkan literasi-lierasi normatif dan yuridis serta diskusi dengan pakar ekonomi syariah di Indonesia. Teknik yang digunakan dalam penelitian ini yaitu content analysis atau kajian isi yang memanfaatkan perangkat prosedur untuk mendapatkan hasil kesimpulan yang benar. Kemudian menggambarkan konsep umum dan realita yang yang ada. Sumber data yang diperoleh berupa literasi baik berupa riset pustaka dari bukubuku bahasa dan ekonomi serta media elektronik yang bersumber dari web/domain/situs lembaga keuangan terkait hingga wawancara kepada orang pribadi yang berstatus sebagai pakar ekonomi syariah dan anggota DSN-MUI.

\section{PENGERTIAN UANG}

Uang secara umum adalah sesuatu yang dapat dapat diterima secara umum sebagai alat pembayaran yang sah di suatu wilayah tertentu dan sebagai alat pembayaran hutang atau sebagai alat untuk melakukan pembelian barang dan jasa (Mujahidin, 2007:59). Dalam islam secara etimologi uang berasal dari kata naqdu-nuqud, an-naqdu berrti yang baik dari dirham, menggenggam dirham, an-naqdu juga berarti tunai. Uang dalam literatur fikih disebut dengan tsaman atau nuqud (jamak dari naqd) dan didefinisikan oleh para pakar sebagai berikut:

1. Menurut Abdullah Sulaiman, Naqd (uang) adalah segala sesuatu yang menjadi media pertukaran dan diterima secara umum, apa pun bentuk dan dalam kondisi seperti apa pun media tersebut (Abdullah bin sualiman Al-Man, 1996:178).

2. Menurut Muhammad Rawas Qal'ah Ji, Naqd adalah segala sesuatu yang dijadikan harga (tsaman) oleh masyarakat, baik dari logam atau kertas yang dicetak maupun dari bahan lainya, dan diterbitkan oleh lembaga keuangan pemegang otoritas (Muhammad Rawas Qa'lah Ji, 1999:23).

3. Dalam buku yang berjudul Ekonomi Islam, Akhmad Mujahidin mengungkapkan bahwa uang adalah segala sesuatu yang dikenal dan dijadikan sebagai alat pembayaran dalam muamalah manusia. Menurut Imam Al-Ghazali dan Ibnu Khaldun, uang adalah apa 
yang digunakan manusia sebagai media simpanan. Sementara menurut Ibnu Taimiyyah uang dalam islam hanya sebagai alat tukar dan alat ukur nilai (Mujahidin, 2007:60).

4. Adiwarman karim menjelaskan konsep uang dalam islam, didalam islam uang adalam flow concept, dimana uang harus mengalir dan tidak boleh mengendap dan hanya menimbun di suatu tempat saja, islam tidak mengenal motif kebutuhan uang untuk spekulasi karena tidak diperbolehkan. Uang adalah barang publik, milik masyarakat karenanya penimbunan uang yang dibiarkan tidak berproduktif berarti mengurangi jumlah uang yang beredar, yang akan berdampak pada kelesuan ekonomi dan stagnansi (terhenti). Dalam islam uang berfungsi sebagai alat pertukaran, namun uang bukan sebuah komoditi. Dalam istilah ekonomi klasik disebutkan bahwa uang tidak memberikan kegunaan langsung yang artinya jika uang digunakan untuk membeli barang, maka barang itu akan memberikan kegunaan (Karim, 2018:77).

5. Menurut Prof Wahbah Az Zuhaili, mata uang secara umum baik emas maupun perak, atau mata uang yang berlaku seperti potongan-potongan logam berbentuk uang yang disepakati nilainya, atau harganya, termasuk juga uang kertas yang dipakai di zaman ini dapat berfungsi sebagai harga jika difungsikan sebagai alat penukar barang yang dibeli. Beliau juga menambahkan menurut mayoritas ulama Hanafi biasanya harga adalah yang tidak bisa ditentukan wujudnya (Wahbah az-Zuhaili, 2019:73-76).

6. Menurut Ibnu Khaldun yang disampaikan oleh Adiwarman Karim uang haruslah berupa emas atau perak, karena dua hal tersebut yang secara alamiah dijadikan sebagai satuan nilai oleh Allah, penggunaan uang logam (kartal) yang oleh penguasa dijadikan alat tukar harus tetap tunduk kepada nilai emas dan perak serta tidak bisa mengubah nilai emas dan perak yang terkandung dalam uang kartal tersebut (Karim, 2004:366).

Dari beberapa pengertian uang diatas, dapat disimpulkan bahwa uang adalah simbolis yang disepakati manusia untuk menentukan harga atau nilai suatu barang, Uang berisiko melemahkan ekonomi suatu tempat apabila ia disimpan saja, sebaliknya perputaran uang yang cepat akan menumbuhkan ekonomi yang cepat pula.

\footnotetext{
UANG ELEKTRONIK, UANG DIGITAL (CRYPTOCURRENCY) DAN

20 FATWA DSN-MUI NO.116 TENTANG UANG ELEKTRONIK Mulvi Aulia
} 


\section{FUNGSI UANG}

1. Sebagai Satuan Nilai. (Unit of Account)

Uang dalam fungsinya sebagai satuan pengukur nilai, maka setiap barang yang dipertukarkan dapat dinilai dengan satuan tertentu. Uang dipakai untuk menunjukan nilai berbagai macam barang dan jasa ynag diperjualbelikan, menunjukan besarnya kekayaan, dan menghitung besar kecilnya pinjaman. Dan uang juga dipakai untuk menentukan harga barang atau jasa (Lestari, $t t: 12$ ). Fungsi pertama ini sesungguhnya merupakan makna dari mata uang.

2. Uang Sebagai Media Pertukaran. (medium of exchange) Uang adalah fisik alat tukar yang digunakan oleh setiap individu untuk pertukaran komoditas dan jasa. Misalnya seseorang memiliki buah apel dan membutuhkan beras, kalau dalam sistem barter pemilik apel mencari beras untuk dipertukarkan dengan apel miliknya. Ketikan orang-orang sudah membuat uang, pemilik apel dapat menjual barangnya dengan imbalan uang, kemudia dengan uang itu ia gunakan untuk membeli beras (Hasan, 2004:12).

3. Media Penyimpan Nilai. (Store of Value)

Menurut para ahli ekonomi, uang sebagai penyimpan nilai atau kekayaan. uang digunakan untuk mengalihkan daya beli dari masa sekarang ke masa mendatang. orang yang mendapatkan uang, kadang tidak mengeluarkan seluruhnya dalam satu waktu tapi ia sisihkan sebagian untuk membeli barang atau jasa yang ia butuhkan pada waktu yang ia inginkan, atau ia simpan untuk halhal tak terduga seperti sakit mendadak atau menghadapi kerugian yang tak terduga (Lestari, t.t:12). Dalam fungsi ini penulis menganggap uang bukan sesuatu yang bisa diinvestasikan, uang harus diubah dulu menjadi modal baru bisa diinvestasikan.

4. Sebagai Pembayaran Tunda

Sebagian ahli ekonomi berpendapat bahwa proses jual beli tidak selalu selesai dengan uang kontan, sekiranya pemilik barang menjual barangnya di pasar dan bertemu dengan pembeli yang sedang tidak membawa uang, lalu penjual menjual barang dengan pembayaran tunda atau dihutangkan (Hasan, 2004:12).

Pada dasarnya dalam Islam uang hanya berfungsi sebagai unit of account dan medium of exchange. Saat uang diperlakukan sebagai komoditas, berkembanglah apa yang disebut dengan pasar uang. Pasar 
uang ini kemudian berkembang dengan munculnya pasar derivatif yang menggunakan instrumen bunga dan terdapat unsur spekulatif disitu, akibat pertukaran yang tidak tunai.

\section{E. KONSEP UANG ELEKTRONIK}

1. Pengertian Uang Elektronik

Uang elektronik didefinisikan sebagai alat pembayaran dalam bentuk uang elektronik dimana nilai uangnya disimpan dalam media elektronik tertentu (Bank Indonesia). Dalam salah satu publikasi pada bulan oktober 1996, Bank of International Settlement (BIS) memberikan definisi tentang uang elektronik sebagai nilai tersimpan atau produk prabayar dimana catatan dana atau nilai uang yang tersedia bagi konsumen disimpan pada perangkat yang dimiliki oleh konsumen (pengguna uang elektronik). Definisi ini mencakup kartu prabayar (disebut juga dompet digital) dan produk perangkat lunak prabayar yang menggunakan jaringan komputer seperti internet (penggunaan internet untuk melakukan pembayaran kartu kredit atau untuk perbankan online umum) (Bank for International Settlements, 2004). Dalam hal produk berbasis kartu, nilai prabayar biasanya disimpan dalam sebuah chip mikroprosessor tertanam dalam kartu plastik, seperti smartcard. Pada sisi lain, network based produk menggunakan software khusus yang di-instal pada komputer pribadi untuk menyimpan "nilai uang". Pemuatan nilai uang keperangkat ini mirip dengan penarikan uang tunai dari ATM, dan produk ini digunakan untuk transaksi pembayaran dalam rangka pembelian barang dan jasa melalui transfer uang ke perangkat elektronik yang dimiliki merchant (Bank for International Settlements, 2004:2).

Sebagai bank sentral yang memiliki peran menjaga kestabilan moneter nasional, Bank Indonesia mengeluarkan regulasi terkait yang elektronik di dalam Peraturan Bank Indonesia no 16/8/PBI/2014 Tentang Perubahan atas Peraturan Bank Indonesia no 11/12/PBI/2009 Tentang Uang Elektronik. Di dalam pasal 1 ayat 3 disebutkan uang elektronik didefinisikan sebagai alat pembayaran yang memenuhi unsur sebagai berikut:

a) Diterbitkan atas dasar nilai uang yang disetor terlebih dahulu kepada penerbit.

b) Nilai uang disimpan secara elektronik dalam suatu media seperti server atau chip. 
c) Digunakan sebagai alat pembayaran kepada pedagang yang bukan merupakan penerbit uang elektronik tersebut; dan

d) Nilai uang elektronik yang dikelola oleh penerbit bukan merupakan simpanan sebagaimana dimaksud dalam Undangundang yang mengatur mengenai perbankan (Peraturan Bank Indonesia No. 16/8/PBI/2014).

Sedangkan dalam fatwa DSN-MUI No.116 Tahun 2017 tentang uang elektronik syariah disebutkan bahwa uang elektronik adalah alat pembayaran yang memenuhi unsur-unsur sebagai berikut:

a) Diterbitkan atas dasar nilai uang yang disetor terlebih dahulu kepada penerbit.

b) Jumlah nominal uang disimpan secara elektronik dalam suatu media yang teregistrasi.

c) Jumlah nominal uang elektronik yang dikelola oleh penerbit bukan merupakan simpanan sebagaimana dimaksud dalam undangundang yang mengatur mengenai perbankan, dan

d) Digunakan sebagai alat pembayaran kepada pedagang yang bukan merupakan penerbit uang elektronik tersebut (Fatwa DSN-MUI No. 116 tentang Uang Elektronik Syariah).

Sesuai dengan Surat Edaran Bank Indonesia No. 16/11/DKSP Perihal Penyelenggaraan Uang Elektronik (Elektronik Money), Uang Elektronik dibedakan menjadi 2 (dua) jenis yaitu:

a) Uang elektronik yang mana identitas Pemegangnya terdaftar dan tercatat pada Penerbit (registered); dan

b) Uang elektronik yang data identitas Pemegangnya tidak terdaftar dan tidak tercatat pada Penerbit (unregistered).

Dari paparan diatas dapat disimpulkan bahwa uang elektronik adalah alat bayar yang merupakan turunan dari uang kartal/Rupiah dalam bentuk kertas dan logam hanya saja nominalnya tersimpan dalam media elektronik, bukan diterbitkan oleh Bank Indonesia (Hotbin Sigalingging, et. al., 2004:23) dan secara legitimasi berbeda dengan uang digital seperti blokchain. Ada beberapa pihak yang terlibat dalam sistem pembayaran elektronik ini, mengingat nilainya yang mewakili uang kartal tersimpan dalam media elektronik seperti server dan chip. 


\section{Para Pihak Dalam Transaksi Uang Elektronik}

Transaksi uang elektronik melibatkan beberapa pihak pada pelaksanaanya. Dalam pelaksaan transaksi uang elektronik tidak hanya penerbit kartu dengan merchant saja atau penerbit dengan pemegangg kartu, melainkan ada beberapa pihak lainya yaitu prinsipal, acquirer, penyelenggara kliring, penyelenggara penyelesaian akhir, dan agen layanan keuangan digital.

Peraturan Bank Indonesia No. 16/8/PBI/2014 Tentang Perubahan atas Peraturan Bank Indonesia No. 11/12/PBI/2009 Tentang Uang Elektronik (elektronik money) dan Fatwa Dewan Syariah Nasional No. 116/DSNMUI/IX/2017 Tentang Uang Elektronik Syariah menjelaskan para pihak yang terlibat dalam transaksi uang elektronik yaitu:

a) Penerbit adalah bank atau lembaga selain bank yang menerbitkan uang elektronik.

b) Pedagang adalah penjual barang dan/atau jasa yang menerima transaksi pembayaran dari pemegang.

c) Pemegang adalah pihak yang memegang uang elektronik.

d) Prinsipal adalah bank atau lembaga selain bank yang bertanggung jawab atas pengelolaan sistem dan/atau jaringan antar anggotanya dan berperan sebagai perebit dan/atau acquirer, dalam transaksi uang elektronik yang bekerjasama dengan anggotanya didasarkan atas suatu perjanjian tertulis.

e) Acquirer adalah bank atau lembaga selain bank yang melakukan kerjasama dengan pedagang, sehingga pedagang mampu memproses transaksi dari uang elektronik yang diterbitkan oleh penerbit selain acquirer yang bersangkutan dan bertanggung jawab atas penyelesaian pembayaran kepada pedagang.

f) Penyelenggara kliring adalah bank atau lembaga selain bank yang melakukan perhitungan hak dan kewajiban keuangan masingmasing penerbit dan/atau acquirer dalam rangka transaksi uang elektronik.

g) Penyelenggara penyelesaian akhir adalah bank atau lembaga selain bank yang melakukan dan bertanggung jawab atas penyelesaian atas hak dan kewajiban keuangan masing-masing penerbit dan/atau acquirer dalam rangka transaksi uang elektronik berdasarkan hasil perhitungan penyelenggara kliring, dan 
h) Agen layanan keuangan digital adalah pihak ketiga yang bekerja sama dengan penerbit dan bertindak untuk dan atas nama penerbit dalam memberikan layanan keuangan digital.

Secara garis besar terdapat 8 (delapan) fungsi operasional dalam sistem pembayaran uang elektronik ini, yaitu: penerbit uang elektronik, pemegang uang elektronik, penjual atau yang menerima pembayaran dengan uang elektronik, pengelola sistem atau jaringan untuk pihakpihak yang terlibat dalam sistem pembayaran dengan uang elektronik, pemroses sistem pembayaran ini, penghitung hak dan kewajiban penerbit/acquirer, yang menyelesaikan hak dan kewajiban berdasarkan perhitungan sebelumya, pelayan keuangan digital yang bertindak atas nama penerbit.

Dari paparan diatas dapat disimpulkan bahwa terdapat sekurangkurang 4 (empat) pihak dalam sistem pembayaran ini, yaitu: otoritas sistem keuangan (Bank Sentral) yang memberikan izin dan pengawasan terhadap sistim pembayaran uang elektronik, bank umum atau lembaga selainnya yang bertindak sebagai penerbit-prinsipalacquirer-penyelenggara kliring dan penyelesaian akhir, pengguna uang elektronik yang dapat bertindak sebagai pemegang maupun penerima pembayaran dengan uang elektronik, agen layanan digital yang memberikan pelayanan keuangan digital.

\section{F. TINJAUAN FIKIH TENTANG UANG ELEKTRONIK}

1. Landasan sistim pembayaran yang bersumber dari AlQuran

a) Al-Kahfi ayat 19:

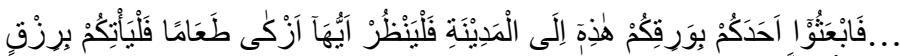

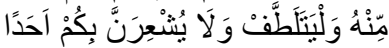

"Maka suruhlah salah seorang di antara kamu pergi ke kota dengan membawa uang perakmu ini, dan hendaklah dia lihat manakah makanan yang lebih baik, dan bawalah sebagian makanan itu untukmu, dan hendaklah dia berlaku lemah lembut dan jangan sekali-kali menceritakan halmu kepada siapa pun."

Dalam tafsir al-Madinah al-Munawwarah/Markaz Ta'dzimul Quran, disebutkan bahwa yang dimaksud dengan ورق adalah perak yang telah dibentuk. Begitupula dalam Tafsir al-Wajiz, ورق dimaknai dari kepingan-kepingan Dirham yang mereka (ashhabul kahfi) bawa sebelum ke gua (Nukhbah al-Ulama, 2010).

b) An-Nisa ayat $29 \& 58$ : 


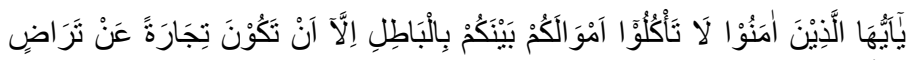

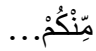

"Wahai orang-orang yang beriman! Janganlah kamu saling memakan harta sesamamu dengan jalan yang batil (tidak benar), kecuali dalam perdagangan yang berlaku atas dasar suka sama suka di antara kamu..."

Dalam Tafsir al-Mukhtashar, dijelaskan bahwa cara yang batil yaitu cara yang dilarang oleh syariat, seperti mencuri, menipu, merampas, berjudi, bertransaksi dengan riba (Jama'atu Ulama at-Tafsir, Tafsir alMukhtasar, Surah An-Nisa). Makna تراض atau suka sama suka berarti kedua belah pihak yang bertransaksi mengetahui apa yang diambilnya tanpa ada kecurangan, penyembunyian aib, penipuan hingga kedua belah pihak berpisah dengan sukarela (Nukhbah al-Ulama, 2010).

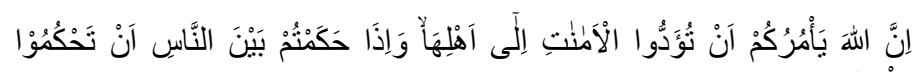

"Sungguh, Allah menyuruhmu menyampaikan amanat kepada yang berhak menerimanya, dan apabila kamu menetapkan hukum di antara manusia hendaknya kamu menetapkannya dengan adil."

c) Al-Maidah ayat 1 :

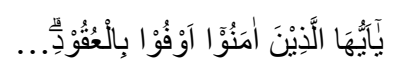

"Wahai orang-orang yang beriman! Penuhilah janji-janji..."

d) Al-Isra ayat 34:

“...dan penuhilah janji, karena janji itu pasti diminta pertanggungjawabannya."

e) Al-Baqarah ayat 282:

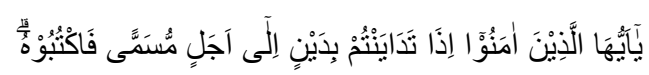

"Wahai orang-orang yang beriman! Apabila kamu melakukan utang piutang untuk waktu yang ditentukan, hendaklah kamu menuliskannya..."

Menuliskan nilai hutang, waktunya, beserta jatuh temponya dilakukan semata-mata untuk menghindari pertikaian dan menjauhi perselisihan.

2. Landasan yang bersumber dari hadis.

a) Hadis yang diriwayatkan dari Abu Sa'id al-Khudri (Hadits Shahih Muslim Jilid 1-4)

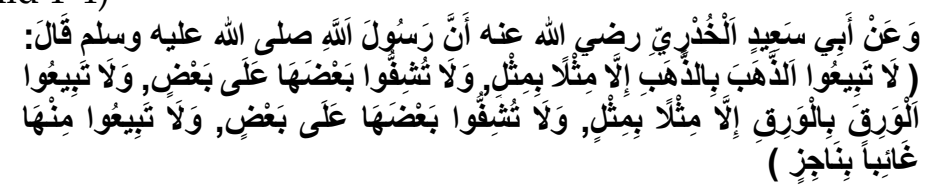


"Dari Abu Said Al-Khudry Radliyallaahu 'anhu bahwa Rasulullah Shallallaahu 'alaihi wa Sallam bersabda: "Janganlah menjual emas dengan emas kecuali yang sama sebanding dan jangan menambah sebagian atas yang lain; janganlah menjual perak dengan perak kecuali yang sama sebanding dan jangan menambah sebagian atas yang lain, dan janganlah menjual perak yang tidak tampak dengan yang tampak."(tidak tunai dengan yang tunai).

b) Hadis yang diriwayatkan dari Abu Hurairah dan Abu Said alKhudri

$$
\text { من استأجر أجير ا فليعلمه أجره }
$$

"Barang siapa yang memperkerjakan pekerja, maka beritahukanlah upahnya"

3. Kaidah Fiqih

$$
\text { الأصل فى المعاملات الإباحة حتى يدل الدليل على تحريمه }
$$

"Hukum asal bermuamalah adalah boleh, hingga ada dalil yan menunjukan keharamanya."

\section{Pendapat Ulama}

Imam Malik al-Ashbahi berpendapat "Andaikan Masyarakat membolehkan uang dibuat dari kulit dan dijadikan sebagai alat tukar, pasti saya melarang uang kulit itu ditukar dengan emas dan perak secara tidak tunai" (Imam Malik bin Annas Al-Ashbahi, 1994:90).

Pendapat Ibnu Hazm "segala sesuatu yang boleh diperjual belikan boleh diguanakan sebagai alat bayar, dan tidak dapat satu nash pun yang menyatakan bahwa uang harus terbuat dari emas dan perak" (Ibnu Hazm, Al-Muhalla, Jilid 8: 477).

Pendapat Ibnu Taimiyah "Adapun dinar dan dirham, maka tidak ada batasan secara alami maupun secara syar"i, tapi rujukanya adalah pada kebiasaan dan kesepakatan. Hal itu karena pada dasarnya tujuan orang (dalam penggunaan dinar dan dirham) tidak berhubungan dengan substansinya, tetapi tujuanya adalah agar dinar dan dirham menjadi standar bagi objek transaksi yang mereka lakukan. Fisik dinar dan dirham tidaklah dimaksudkan (bukan tujuan, tetapi hanya sebagai sarana untuk melakukan transaksi denganya. Oleh karena itu, dinar dan dirham (hanya) berfungsi sebagai tsaman (harga, standar nilai). Berbeda dengan harta yang lain (barang), barang dimaksudkan untuk dimanfaatkan fisiknya. Oleh karena itu barang harus diukur dengan perkara (ukuran-ukuran) yang bersifat alami atau syar"i). sarana semata yang fisik maupun bentuknya bukan merupakan tujuan boleh digunakan untuk mencapai tujuan, seperti apapun bentuknya"(Ibnu Taimiyyah, Majmu' Fatawa Islam Ibnu Taimiyyah, Jilid 19: 251). 
5. Fatwa Dewan Syariah Nasional - Majelis Ulama Indonesia

Kehalalan uang elektronik yang sesuai syariah adalah uang elektronik yang sesuai dengan Fatwa Dewan Syariah Nasioanal No. 116/DSNMUI/IX/2017 tentang uang elektronik syariah.

\section{G. PERBEDAAN UANG ELEKTRONIK DAN UANG DIGITAL (CRYPTOCURRENCY)}

Tabel 1. Perbedaan Aspek Normatif Uang Elektronik dengan Cryptocurrency

\begin{tabular}{lcc}
\hline $\begin{array}{c}\text { Aspek Normatif (Peraturan } \\
\text { Bank Indonesia No. 20/6/2018 } \\
\text { tentang Uang Elektronik) }\end{array}$ & $\begin{array}{c}\text { Uang } \\
\text { Elektronik }\end{array}$ & Cryptocurrency \\
\hline $\begin{array}{l}\text { Dibawah Otoritas Keuangan } \\
\text { Sentral }\end{array}$ & Ya & Tidak \\
\hline Kehalalan dari DSN-MUI & Ya & Belum \\
\hline $\begin{array}{l}\text { Diterima masyarakat dalam } \\
\text { bertransaksi online }\end{array}$ & Ya & Belum seluruhnya \\
\hline Derivasi dari uang kartal & Ya & Tidak \\
\hline
\end{tabular}

Tabel 2. Perbedaan Aspek Fungsi Uang Elektronik dengan Cryptocurrency

\begin{tabular}{l|c|l}
\hline \multicolumn{1}{c|}{ Aspek Fungsi } & \multicolumn{1}{|c}{ Uang Elektronik } & \multicolumn{1}{|c}{ Cryptocurrency } \\
\hline Sebagai satuan nilai & $\begin{array}{l}\text { Ya, mengikuti nilai } \\
\text { currency suatu } \\
\text { negara }\end{array}$ & \multicolumn{1}{|c}{ Ya } \\
\hline $\begin{array}{l}\text { Sebagai alat } \\
\text { pembayaran }\end{array}$ & \multicolumn{1}{|c}{ Ya } & \multicolumn{1}{|c}{ Ya } \\
\hline $\begin{array}{l}\text { Sebagai media } \\
\text { penyimpan nilai }\end{array}$ & $\begin{array}{l}\text { Tidak, nilainya } \\
\text { mengikuti currency } \\
\text { suatu negara. } \\
\text { minner atang ada } \\
\text { kryptoriannya, ingin } \\
\text { apakah } \\
\text { mengunderlyingkanny } \\
\text { a pada sektor riil, aset } \\
\text { pribadi atau dari } \\
\text { transaksi jual beli }\end{array}$ \\
\hline
\end{tabular}




\begin{tabular}{l|l|l}
\hline & & $\begin{array}{l}\text { mata uang (Mardigu } \\
\text { Wowiek, 2018). }\end{array}$ \\
\hline Sebagai komoditas & Tidak & $\begin{array}{l}\text { lya, jika masuk ke } \\
\text { bursa uang yang } \\
\text { diperjualbelikan lalu } \\
\text { memperoleh } \\
\text { keuntungan. }\end{array}$ \\
\hline $\begin{array}{l}\text { Sebagai alat } \\
\text { pembayaran tunda }\end{array}$ & Tidak & \multicolumn{1}{|c}{ Rata-rata iya } \\
$\begin{array}{l}\text { Sebagai pengganti } \\
\text { mata uang }\end{array}$ & Tidak & \multicolumn{1}{c}{ Ya } \\
\hline
\end{tabular}

\section{H. MAKSUD FATWA DSN-MUI No.116}

Dalam fatwa tersebut, DSN-MUI meredakasikan bahwa salah satu unsur uang elektronik adalah: "Jumlah nominal uang disimpan secara elektronik dalam suatu media yang teregistrasi." Hal ini dimaksudkan bahwa uang elektronik adalah derivasi dari uang kartal, dimana satuan nilainya tetap menggunakan mata uang suatu negara. Adapun penerbit dan penyelenggara sistem pembayaran ini, semuanya "teregistrasi" berikut teknologi yang digunakannya, dibawah otoritas keuangan sentral suatu negara.

Fatwa diatas tidak berkaitan dengan jenis uang elektronik berdasarkan tercatat atau tidaknya data identitas pemegang pada penerbit uang elektronik yang dikemukakan oleh Bank Indonesia (Surat Edaran Bank Indonesia No. 16/11/DKSP) yang dibagi menjadi menjadi 2 (dua) yaitu uang elektronik registered dan uang elektronik unregistered (Bank Indonesia, 2021).

\section{G. PENUTUP}

Dari paparan ini ini penulis simpulkan bahwasannya uang elektronik dalam persepsi Bank Indonesia dan Fatwa DSN-MUI sangatlah berbeda dengan apa yang disebut dengan cryptocurrency, di mana uang elektronik merupakan derivasi dari uang kartal dan nilainya mengikuti mata uang suatu negara yang memiliki instrumen Bank Sentral atau otoritas keuangan sentral. Uang elektronik tersimpan dalam media elektronik baik berupa server, chip ataupun nomor handphone dengan komputasi yang terpusat. berbeda dengan 
uang digital di mana uang tersebut hanya ada di dunia maya (internet) yang komputasinya terdesentralisasi. cryptocurrency hadir sebagai emas atau perak nya di dunia nyata untuk menggantikan sistem pembayaran yang tercatat dalam buku besar pada lembaga sentral (terdesentralisasi). Adapun fungsi-fungsi cryptocurrency dapat mewakili fungsi mata uang saat ini, tergantung kepada penambang digital ataupun kryptorian.

Selanjutnya untuk peneliti lain diharapkan tidak menjadikan fatwa DSN-MUI tentang uang elektronik untuk menghukumi cryptocurrency, karena dua hal tersebut berbeda. Adapun maksud fatwa DSN-MUI tentang uang elektronik di mana "jumlah nominal uang tersimpan dalam suatu media yang teregistrasi", yaitu media yang yang digunakan oleh penerbit uang elektronik, pengguna uang elektronik dan pihak ketiga sebagai penyelenggara sistem pembayaran ini, adalah media yang terdaftar dan mendapatkan izin dari bank sentral yaitu Bank Indonesia.

\section{DAFTAR PUSTAKA}

Abdullah, Burhanuddin. (2006). Paper Seminar Internasional Toward a Less Cash Society in Indonesia. Jakarta: Direktorat Akunting dan Sistem Pembayaran Bank Indonesia.

Abdullah Sulaiman Al-Mani. (1996). Buhuts Fi Al-iqtishad Al-islami. Mekah: al-Maktab al-Islami.

Al-imam Muslim. (2005). Hadis Shahih Muslim. Jakarta: Klang Book Centre. Penerjemah: Ma'Mur Daud.

Badan Pengembangan dan Pembinaan Bahasa, Kementerian Pendidikan dan Kebudayaan Republik Indonesia, Kamus Besar Bahasa Indonesia, Versi daring: 3.5.1.1-20201226171802. https://kbbi.kemdikbud.go.id/entri/uang

Bank Indonesia, "Uang Elektronik", https://www.bi.go.id/id/edukasiperlindungan-konsumen/edukasi/produk-dan-jasa-sp/uangelektronik/pages/default.aspx.

Committe on Payment and Settlement System. (2004). Survey of Development in Elektronic Money and Internet and Mobile Payments: Bank for International Settlements, tahun 2004.

Fatwa Dewan Syariah Nasional - Majelis Ulama Indonesia, No:116/DSN-MUI/IX/2017 tentang Uang Elektronik Syariah.

\footnotetext{
UANG ELEKTRONIK, UANG DIGITAL (CRYPTOCURRENCY) DAN

30 FATWA DSN-MUI NO.116 TENTANG UANG ELEKTRONIK Mulvi Aulia
} 
Hasan, Ahmad. (2004). Mata Uang Islam. Jakarta: Raja Grafindo Persada. Hitty, Philip K. (2014). History of The Arabs, Terj. Jakarta: Serambi Ilmu Semesta.

Hotbin Sigalingging, Dkk, Kebijakan Pengedaran Uang di Indonesia (Jakarta: Pusat Pendidikan dan Studi Kebanksentralan Bank Indonesia, 2004).

Ibnu Hazm. (t.t), Al-Muhalla, jilid 8. Jakarta: Pustaka Azzam.

Ibnu Taimiyyah. (t.t). Majmu" Fatawa Islam Ibnu Taimiyyah, jilid 19.

Daarul Wafa. Penerjemah: Amir Al-Jazar-Anwar Al-Baaz.

Ibrahim, Dusuki. (2019). Al-Qawa"id Al-Fighiyah, Kaidah-Kaidah Fiqih. Palembang: CV. Amanah.

Imam Malik Annas Al-Ashbahi. (1994). Al-Mudawwanah Al-Kubro, Jilid 3. Beirut: Darul Kutub Al-Ilmiyah.

Jama'atu Ulama at-Tafsir. (t.t). Tafsir al-Mukhtashar. Riyadh: Markaz alTafsir li al-Dirasat al-Quraniah.

Lestari, Etty Puji. Peranan Uang Dalam Perekonomian. Modul 1.

Karim, Adimarwan Azwar. (2004). Sejarah Pemikiran Ekonomi Islam. Jakarta: PT. Raja Grafindo Persada.

Karim, Adiwarman Azwar. (2018). Ekonomi Makro Islami. Jakarta: PT Raja Grafindo Persada.

Marthon, Said Sa'ad. (2004). Ekonomi Islam diTengah Krisis Ekonomi Global. Jakarta: Zikrul Hakim. Terj. Ahmad Ikhrom dan Dimyauddin.

Muhammad Rawas Qal'ah Ji. (1999). Al-Muamalat Al-Maliyah AlMu"ashiirah Fi Dhau" Al-Figh Wa Al-Syariah. Beirut: Dar AlNafa"is.

Mujahidin, Akhmad. (2007). Ekonomi Islam. Jakarta: Raja Grafindo Persada.

Nukhbah al-Ulama. (2010). Tafsir al-Madinah al-Munawwarah, Jilid 2. Riyadh: Dar as-Sum'ai.

Peraturan Bank Indonesianomor 16/8 /PBI/2014 tentang Perubahan Atas Peraturan Bank Indonesia Nomor 11/12/Pbi/2009 Tentang Uang Elektronik(Electronic Money).

Wahbah az-Zuhaili. (2019). Fiqih Islam Wa Adillatuhu, Jilid.5, Terj. Depok: Gema Insani. 
al-Mizan, Vol. 4, No.1, hlm. 15-32, Februari 2020,

P.ISSN : 2085-6792, E.ISSN : 2656-7164

\section{WAWANCARA}

Penulis melakukan wawancara dengan Dr. Syarif Hidayatullah, M.A., M.C.H.C., mengenai redaksi makna uang elektronik menurut Fatwa DSN-MUI No.116 dan redaksi jenis uang elektronik berdasarkan tercatat atau tidaknya data identitas pemegang pada penerbit uang elektronik yang dikemukakan Bank Indonesia. Beliau merupakan pakar hukum ekonomi syariah sekaligus tenaga pendidik di UIN Syarif Hidayatullah Jakarta \& Institut Ilmu AlQuran Jakarta. 